\title{
Pemahaman Pengelolaan Keuangan Desa Dan Ketepatan Waktu Pertanggungjawaban Dana Desa
}

\author{
${ }^{1 *}$ Yanti Sumiyati, ${ }^{2}$ Icih, ${ }^{3}$ Indah Umiyati \\ ${ }^{1,2,3}$ Sekolah Tinggi Ilmu Ekonomi Sutaatmadja, Indonesia \\ *Email korenpondensi: icih@stiesa. ac. id
}

\begin{abstract}
This study aims to determine the effect of village officials' understanding of village financial management on the timeliness of village fund accountability. The 2015 Subang District village budget of Rp72. 7 billion was channeled from the RKUN to the RKUD Rp38 billion. The remaining budget can be disbursed if the distribution of village funds from the RKUD to the RKD reaches $90 \%$ but until November 2015 it has only reached 77\%. This type of research is a quantitative study using logistic regression. Village financial management consists of village financial planning, implementation, administration, reporting and accountability. The level of understanding of village officials about the planning, implementation, administration of village finance partially has a significant positive effect on the timeliness of village fund accountability, while the understanding of village financial reporting and accountability does not affect the timeliness of village fund accountability. The understanding of village officials about village financial management simultaneously has a significant effect on the timeliness of village fund accountability.
\end{abstract}

Keywords: village financial management, village fund

Saran sitasi: Sumiyati, Y. , Icih. , \& Umiyati, I. (2019). Pemahaman Pengelolaan Keuangan Desa Dan Ketepatan Waktu Pertanggungjawaban Dana Desa. Jurnal Akuntansi dan Pajak, 20(1), 89-98. doi: http://dx. doi. org/10. 29040/jap. v20i1. 372

DOI: http://dx. doi. org/10. 29040/jap. v20i1. 372

\section{Pendahuluan}

Pemerintah Indonesia dibawah pimpinan Presiden Joko Widodo telah meprioritaskan 9 agenda yang dikenal dengan Nawacita. Salah satu isi Nawacita adalah membangun Indonesia dari pinggiran dengan memperkuat daerahdaerah dan desa dalam kerangka NKRI(Peraturan Presiden No. 2 tentang Rencana Pembangunan Jangka Menengah Nasional (RPJMN) Tahun 2015 - 2019, 2015). Pembangunan desa-desa difasilitasi oleh adanya dana desa yang merupakan salah satu sumber pendapatan desa. Dana desa bersumber dari Anggaran Pendapatan dan Belanja Negara (APBN). Dana desa diberikan kepada Desa lewat pemindah bukuan dari Rekening Kas
Umum Negara (RKUN) ke Rekening Kas Umum Daerah (RKUD) Kabupaten yang selanjutnaya k eRekening Kas Desa (RKD)(Presiden Republik Indonesia, 2014). Penyaluran dana desa setiap tahun dilakukan dalam beberap atahap. Penyaluran taha pkedua dan seterusnya dipengaruhi oleh pertanggungjawaban dana desa tahap sebelumnya. Hal inilah yang diduga mengakibatkan keterlambatan penyaluran dana desa.

Indonesia terdiri dari 34 provinsi terbagi menjadi 514 Kabupaten/Kota yang terdiri dari 8. 412 kelurahan dan 74. 093 desa(Menteri Dalam Negeri Republik Indonesia, 2015). Desa merupakan tujuan dana desa. Dana Desa tahun 


\section{Jurnal Akuntansi dan Pajak, 20(01), 2019, 90}

\section{5 sebesar Rp20,776 triliun(Presiden} Republik Indonesia, 2015b), sehingga masingmasing desa akan memperoleh Rp250 juta hingga Rp280 juta. Penyaluran dana desatahun 2015 mengalami keterlambatan. Menurut data Kementerian Keuangan Republik Indonesia, sampai tanggal 13 November 2015 dana desa yang sudah disalurkan dari RKUD ke Rekening Kas Desa (RKD) baru mencapai Rp 6,2 triliun. Dari 434 kabupaten/kota, baru 244 kabupaten/kota yang melaporkan penyaluran dari RKUD ke RKD. Untuktahap I, 136 dari 244 daerah telah menyalurkan seluruh dana desa ke desa sebesar Rp2,89 triliun atau 34,7\%, dan 84 daerah baru menyalurkan sebagian kecil dana desa sebesar Rp 1,16 triliunatau $14 \%$ dan 24 daerah belum menyalurkan sama sekali. Sedangkan untuk tahap II, sebanyak 129 daerah sudah menyampaikan laporannya. Terdapat 59 daerah telah menyalurkan seluruh dana desa dengan jumlah Rp1,23 triliun atau 14,9\%, 66 daerah baru menyalurkan sebagian dana desa sebesar Rp968 atau 11,7\% dan sisanya belum sama sekali(Menteri Keuangan Republik Indonesia, 2015). Hal yang sama terjadi di tahun 2018, sampai dengan 16 April 2018 penyaluran transfer untuk program dana desamencapai Rp12,23 triliunatau 20,4\% dari pagu sebesar Rp60 triliun. Sayangnya, dari jumlah realisasi penyaluran dana desake RKUD tersebut, penyalurandari RKUD ke RKD baru mencapai Rp 2,1 triliun, untuk 140 Daerah dan 12. 343 Desa(Ipak Ayu H Nurcaya, n. d. ).

Kabupaten Subang mendapat alokasi anggaran dana desa tahun 2015sebesar Rp72,7 miliar(Presiden Republik Indonesia, 2015a). Dana desa ini akan disalurkan kepada 245 desa yang ada di Kabupaten Subang. Dana desa yang sudah masuk ke RKUD Subang sebesar Rp38 Miliar, dan sisanya sebesar Rp34,7 miliar masih tersimpan di rekening pusat. Sisa dana desa yang tersimpan di rekening pusat ini dapat dicairkan apabila penyaluran dana desa sebesar Rp38 Miliar dari RKUD Subang ke RKD tiap desa telah mencapai $90 \%$. Namun hingga bulan November 2015, dana desa yang sudah disalurkan dari RKUD ke RKD adalah sebesarRp29,6 Miliar atau sebesar 77\% (Yusuf Adji, 2015). Hal yang sama terjadi di tahun 2018, sampai dengan bulan Agustus 2018 dana desa di Kabupaten Subang baru terserap 60\%(Efendi, 2018).

Di bawah ini data dana desa di Kabupaten Subang tahun 2015 dan 2017 per kecamatan.

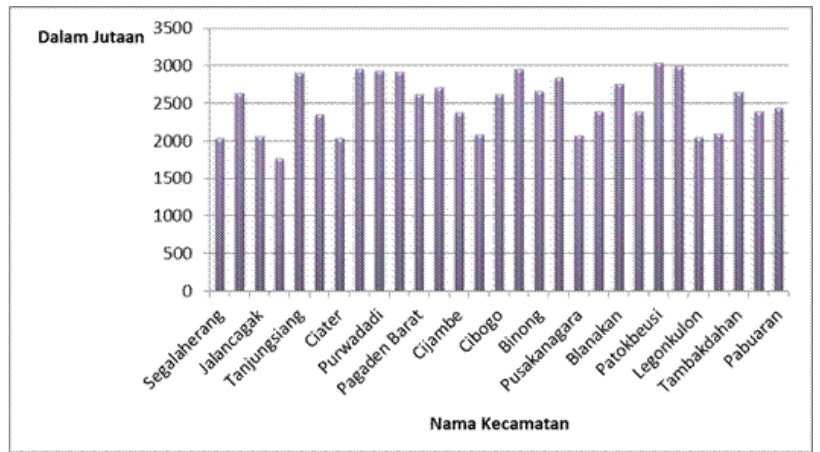

Gambar 1 JumlahDana Desa 2015 per Kecamatan di Kabupaten Subang Sumber: Data PemerintahKabupaten Subang yang diolah (2016)

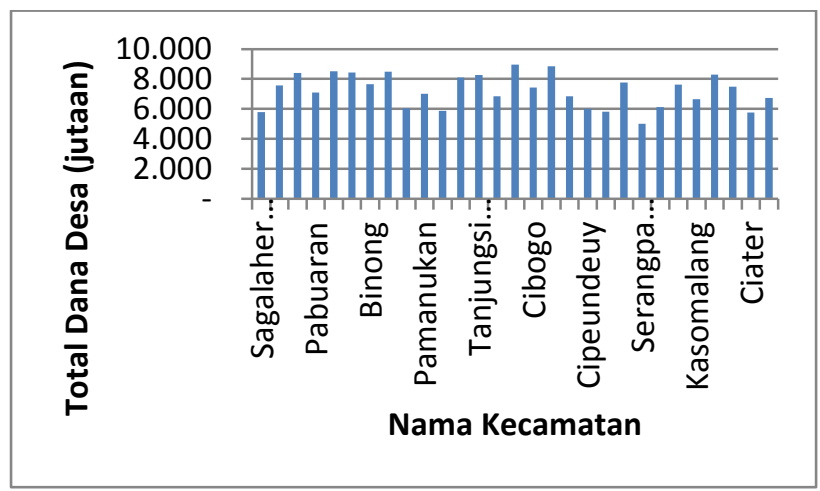

Gambar 2 Jumlah Dana Desa 2017 per Kecamatan di Kabupaten Subang

Sumber: Data PemerintahKabupaten Subang yang diolah (2018)

Masih kecilnya penyerapan dana desa oleh setiap desa ini terjadi karena terkendala laporan pertanggungjawaban penggunaan dana desa. Penyerapan anggaran dana desa tahap satu relative lebih lancar karena untuk mencairkannya belum disyaratkan laporan pertanggungjawaban (Yusuf Adji, 2015). Terlambatnya penyerapan dana desa tahap dua terjadi karena keterlambatan penyampaian laporan pertanggungjawaban tahap satu yang menjadi syarat pencairan dana tahap dua dan tiga. Keterlambatan waktu pertanggungjawaban 


\section{Jurnal Akuntansi dan Pajak, 20(01), 2019, 91}

dana desa diduga dipengaruhi oleh pemahaman aparat desa terhadap pengelolaan keuangan desa. Pemahaman merupakan aspek perilaku manusia. Seseorang dikatakan paham terhadap akuntansi jika mengerti dan pandai bagaimana proses akuntansi itu dilakukan sampai menjadi suatu laporan keuangan dengan berpedoman pada prinsip dan standar penyusunan laporan keuangan yang ditetapkan (Yuliani, Safrida. , Nadirsyah,. Bakar, 2010). Akuntansi tidak dapat dilepaskan dari aspek perilaku manusia. Hubungan antara perilaku manusia dengan system akuntansi menghasilkan ilmu akuntansi keperilakuan (Manansal, 2013). Akuntansi keperilakuan merupakan sub disiplin ilmu yang melibatkan aspek-aspek keperilakuan manusia terkait dengan proses pengambilan keputusan ekonomi (Lubis, 2014)

Pengelolaan keuangan desa adalah keseluruhan kegiatan yang meliputi perencanaan, pelaksanaan, penatausahaan, pelaporan, dan pertanggungjawaban keuangan desa (Menteri Dalam Negeri Republik Indonesia, 2014). Kepala Desa sebagai pemegang kekuasaan dalam pengelolaan keuangan desa dibantu oleh Pelaksana Teknis Keuangan Desa (PTPKD) dalam hal ini adalah Sekretaris Desa sebagai Koordinator, KepalaSeksi, dan Bendahara (Menteri Dalam Negeri Republik Indonesia, 2014),sebagai Koordinator Pengelolaan Keuangan Desa mereka sangat dituntut dapat memahami pengelolaan keuangan desa sehingga pelaporan dan pertanggungjawaban penggunaan keuangan desa bisa dilakukan secara tepat waktu. Dana desa tersebut bersumber dari belanja pemerintah dengan mengefektifkan program berbasis desa secara merata dan berkeadilan (Presiden Republik Indonesia, 2014) (Presiden Republik Indonesia, 2016). Dengan peningkatan penerimaan desa ini diperlukan adanya laporan pertanggungjawaban dari desa (Sujarweni, 2015).

Beberapa penelitian mengenai pemahaman terhadap proses pengelolaan keuangan dan akuntansi terhadap pelaporan keuangan telah dilakukan. Hasil penelitiannya menunjukkan ada pengaruh yang signifikan antara pemahaman akuntansi aparat pemerintah kota Banda Aceh terhadap kualitas laporan keuangan yang dihasilkan (Yuliani, Safrida. , Nadirsyah,. Bakar, 2010). Adanya pengaruh yang positif dan signifikan antara pemahaman piñata usahaan keuangan daerah terhadap kinerja pengelolaan keuangan daerah (Sari, Erna. , Saiful. Aprilia, 2013). Penelitian lain mengemukakan hal yang berbeda dimana pemahaman system keuangan daerah secara parsial tidak berpengaruh terhadap pengelolaan keuangan daerah (Sugeng, 2014).

Mengacu pada uraian di atas, dapat disimpulkan bahwa penelitian-penelitian mengenai pengaruh pemahaman individu tentang pengelolaan keuangan terhadap kualitas pelaporan keuangan pun belum konklusif. Selain itu, belum ada penelitian yang secara spesifik meneliti mengenai pengaruh pemahaman aparat desa tentang pengelolaan keuangan desa terhadap ketepatan waktu pertanggungjawaban dana desa. Pengelolaan keuangan desa terdiri dari pemahaman perencanaan, pelaksanaan, piñata usahaan, pelaporan, dan pertanggungjawaban keuangan desa.

Berdasarkan research gap tersebut, penelitian ini mencoba menjawab permasalahan mengenai sejauh mana pemahaman terhadap pengelolaan keuangan desa dapat mempengaruhi kualitas pelaporan keuangan yang dilihat dari ketepatan waktu pertanggungjawaban. Penelitian ini bertujuan meneliti pemahaman aparat desa selaku pihak yang memiliki kuasa atas pengelolaan keuangan desa sesuai dengan Permendagri No. 113 Tahun 2014 dan bagaimana pengaruhnya terhadap ketepatan waktu pertanggungjawaban dana desa. Adapun hipotesis dalam penelitian ini adalah sebagai berikut:

Jika aparat desa paham terhadap perencanaan keuangan desa maka diduga pertanggungjawaban dana desa dapat diselesaikan secara tepat waktu. Aspek 


\section{Jurnal Akuntansi dan Pajak, 20(01), 2019, 92}

perencanaan ini berhubungan dengan penyusunan anggaran yang terdapat dalam RPJP dan APBDes. Berdasarkan penelitian sebelumnya (Winarna, Jaka. , Murni, 2006), mengemukakan bahwa pengetahuan tentang rencana anggaran dan deteksi terhadap pemborosan atau kegagalan, dan kebocoran anggaran berpengaruh positif terhadap pengawasan keuangan daerah. Berdasarkan hal tersebut maka hipotesis pertama adalah:

\section{H1: Pemahaman aparat desa tentang} perencanaan keuangan desa (X1) berpengaruh positif signifikan terhadap ketepatan waktu pertanggungjawaban dana desa.

Aspek berikutnya adalah pelaksanaan. Jika aparat desa paham terhadap pelaksanaan keuangan desa maka diduga pertanggungjawaban dana desa dapat diselesaikan secara tepat waktu. Penelitian sebelumnya mengemukakan bahwa implementasi pengelolaan keuangan berpengaruh positif dan signifikan terhadap kualitas laporan keuangan (Charolina, Ovita. , Husaini, 2013). Hal ini menunjukan bahwa semakin tinggi tingkat implementasi pengelolaan keuangan maka semakin tinggi pula tingkat kualitas laporan keuangan, khususnya tepat waktu. Berdasarkan hal tersebut maka hipotesis kedua adalah:

H2: Pemahaman aparat desa tentang pelaksanaan keuangan desa (X2) berpengaruh positif signifikan terhadap ketepatan waktu pertanggungjawaban dana desa.

Pemahaman terhadap piñata usahaan keuangan daerah oleh pengelola keuangan daerah berpengaruh positif terhadap kinerja satuan kerja pemerintah daerah(Ratih, 2012). Semakin baik pemahaman aparatur pengelola keuangan daerah terhadap piñata usahaan keuangan daerah akan mampu meningkatkan kinerja pengelolaan keuangan daerah. Terkait dengan tahapan piñata usahaan dana desa, maka diduga jika aparat desa paham terhadap piñata usahaan keuangan desa maka pertanggungjawaban dana desa dapat diselesaikan secara tepat waktu. Berdasarkan hal tersebut maka hipotesis ketiga adalah:

\section{H3: Pemahaman aparat desa tentang piñata usahaan keuangan desa (X3) berpengaruh positif signifikan terhadap ketepatan waktu pertanggungjawaban dana desa.}

Laporan keuangan merupakan laporan yang terstruktu rmengenai posisi keuangan dan transaksi-transaksi yang dilakukan oleh suatu entitas pelaporan. Secara spesifik, tujuan pelaporan keuangan pemerintah adalah untuk menyajikan informasi yang berguna untuk pengambilan keputusan dan untuk menunjukkan akuntabilitas entitas pelaporan atas sumber daya yang dipercayakan kepadanya (Aliyah \& Nahar, 2012). Penyajian laporan keuangan daerah berpengaruh positif dan signifikan terhadap transparansi dan akuntabilitas pengelolaan keuangan daerah dan aksesibilitas laporan keuangan daerah juga berpengaruh positif dan signifikan terhadap transparansi dan akuntabilitas pengelolaan keuangan daerah (Aliyah \& Nahar, 2012). Sedangkan secara bersama-sama, penyajian laporan keuangan daerah dan aksesibilitas laporan keuangan daerah secara simultan berpengaruh positif dan signifikan terhadap transparansi dan akuntabilitas pengelolaan keuangan daerah. Terkait dengan tahapan pelaporan dana desa, maka diduga jika aparat desa paham terhadap pelaporan keuangan desa maka pertanggungjawaban dana desa dapat diselesaikan secara tepat waktu. Berdasarkan hal tersebut maka hipotesis keempat adalah:

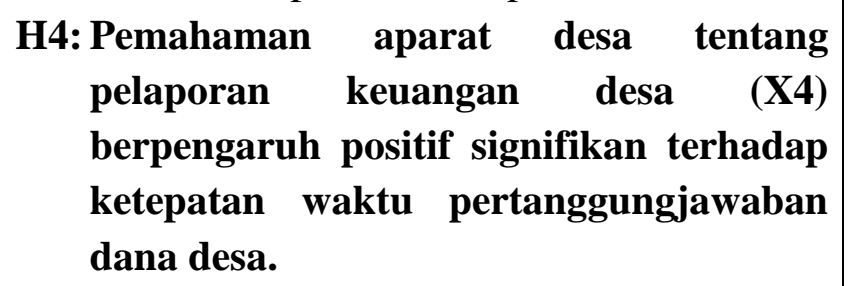




\section{Jurnal Akuntansi dan Pajak, 20(01), 2019, 93}

Pemahaman system akuntansi keuangan daerah yang didalamnya tercakup aspek pertanggungjawaban terbukti dapat mempengaruhi kualitas informasi laporan keuangan pemerintah daerah(Dewi. , 2014). Hal ini berarti bahwa semakin baik pemahaman pegawai terhadap system akuntansi keuangan daerah, maka kualitas informasi laporan keuangan pemerintah daerah semakin meningkat. Berdasarkan hasil penelitian yang telah dilakukan, bahwa pemahaman akuntansi keuangan daerah dan pengelolaan keuangan daerah terbukti dapat mempengaruhi kualitas informasi laporan keuangan pemerintah daerah. Terkait dengan tahapan pertanggungjawaban dana desa, maka diduga jika aparat desa paham terhadap pertanggungjawaban dana desa maka pertanggungjawaban dana desa dapat diselesaikan secara tepat waktu. Berdasarkan hal tersebut maka hipotesis kelima adalah

\section{H5: Pemahaman aparat desa tentang pertanggungjawaban keuangan desa (X5) berpengaruh positif signifikan terhadap ketepatan waktu pertanggungjawaban dana desa.}

H6: Pemahaman aparat desa tentang pengelolaan keuangan desa berpengaruh terhadap ketepatan waktu pertanggungjawaban dana desa.

\section{Metode Penelitian}

Penelitian ini merupakan penelitian kuantitatif. Populasi yang digunakan dalam penelitian ini adalah desa yang ada di Kabupaten Subang yaitu 245 desa. Responden dari penelitian inia dalah kepala desa atau sekretaris desa. Metode pengambilan sampel yang digunakan adalah convenience sampling. Dari 245 kuesioner yang disebar kepada seluruhdesa di Kabupaten Subang, diperoleh 52 desa yang mengisi kuesioner. Ukuran sampel lebih dari 30 dan kurang dari 500 adalah tepat untuk kebanyakan penelitian(Sekaran, 2006). Penelitian ini dilakukan terhadap dana desa tahun 2015. Keterlambatan penyaluran dana desa masih berlangsung sampai dengan dana desa tahun 2018, sehingga data dana desa tahun 2015 dianggap masih mewakili kondisi pertanggungjawaban dana desa tahun 2018.

Penelitian ini menggunakan data primer dan data sekunder. Data primer berupa kuesioner pemahaman aparat desa terhadap pengelolaan keuangan dana desa yang dibagikan kepada kepala desa atau sekretaris desa. Data sekunder berupa data pertanggungjawaban dana desa yang diperoleh dari Pemda Kabupaten Subang.

Variabel yang digunakan dalam penelitian ini adalah Ketepatan Waktu Pertanggungjawaban Dana Desa sebagai variabel dependen (Y). Desa akan diberi nilai 1 jika tepat waktu dalam menyampaikan laporan pertanggungjawaban dana desanya, dan diberinilai 0 jika sebaliknya. Variabel independen diukur menggunakan skala Likert. Jarak respon dari pernyataan di dalam kuesioner ada dalam rentang 1 sampai dengan 5 , dimana 1 = Sangat Tidak Paham, 2 = TidakPaham, 3 = Cukup Paham, 4 = Paham, dan 5 = Sangat Paham.

\section{Hasil dan Pembahasan}

Hasil uji validitas untuk kuisioner dengan $\mathrm{dk}$ atau $\mathrm{df}=52-2=50$ pada tingkat signifikansi $(\propto)$ sebesar 5\% atau 0,05 diperoleh nilai $r_{\text {tabel }}=0,2306$,dimana $r_{\text {hitung }}>r_{\text {tabel }}$ hal ini menunjukkan bahwa item-item ini sudah valid. Dari hasil pengujian realibilitas untuk variabel $\mathrm{X} 1, \mathrm{X} 2, \mathrm{X} 3, \mathrm{X} 4$, dan X5, menunjukkan bahwa variabel independen masing-masing memiliki nilai cronbrach's alpha alpha $>0,60$. sehingga variabel X1, X2, X3, X4, dan X5 reliabel(Hair, 1998).

Karakteristik responden penelitian dijelaskan dalam table-tabel di bawah ini.

Tabel. 1

Deskriptif Responden

\begin{tabular}{|l|l|l|}
\hline Karakteristik & Klasifikasi & Persentase \\
\hline JenisKelamin & Laki-laki & $94,2 \%$ \\
\hline & Perempuan & $5,8 \%$ \\
\hline Usia & $21-30$ & $7,7 \%$ \\
\hline & $31-40$ & $34,6 \%$ \\
\hline & $41-50$ & $44,2 \%$ \\
\hline & $>50$ & $34,6 \%$ \\
\hline
\end{tabular}




\begin{tabular}{||l|l|l|}
\hline \multicolumn{3}{c}{ Jurnal Akuntansi dan } \\
\hline Karakteristik & Klasifikasi & Persentase \\
\hline Pendidikan & SMP & $1,9 \%$ \\
\hline & SMA & $75 \%$ \\
\hline & S1 & $23,1 \%$ \\
\hline & S2 & $0,0 \%$ \\
\hline Jabatan & KepalaDesa & $11,5 \%$ \\
\hline & SekretarisDesa & $88,5 \%$ \\
\hline Masa Jabatan & $\leq$ 1 Tahun & $15,40 \%$ \\
\hline & $>$ 1 Tahun & $84,6 \%$ \\
\hline
\end{tabular}

Sumber : Data primer yang diolah, tahun 2016

Tabel 3

StatistikDeskriptif (Variabel X)

\begin{tabular}{|l|c|c|c|c|c|c|c|c|}
\hline \multicolumn{1}{|c|}{ Variabel } & N & $\begin{array}{c}\text { Range } \\
\text { Teoritis }\end{array}$ & $\begin{array}{c}\text { Range } \\
\text { Aktual }\end{array}$ & Min. & Max. & Mean & SD & Var. \\
\hline $\begin{array}{l}\text { Pemahaman Perencanaan Keuangan } \\
\text { Dana Desa (X1) }\end{array}$ & 52 & $1-5$ & 2,37 & 2,04 & 4,41 & 2,92 & 0,58 & 0,339 \\
\hline $\begin{array}{l}\text { Pemahaman Pelaksanaan Keuangan } \\
\text { Dana Desa (X2) }\end{array}$ & 52 & $1-5$ & 2,76 & 1,53 & 4,29 & 2,95 & 0,59 & 0,344 \\
\hline $\begin{array}{l}\text { Pemahaman Penatausahaan } \\
\text { Keuangan Dana Desa (X3) }\end{array}$ & 52 & $1-5$ & 2,66 & 2,04 & 4,70 & 3,24 & 0,68 & 0,463 \\
\hline $\begin{array}{l}\text { Pemahaman Pelaporan Keuangan } \\
\text { Dana Desa (X4) }\end{array}$ & 52 & $1-5$ & 3,10 & 1,38 & 4,48 & 2,98 & 0,77 & 0,587 \\
\hline $\begin{array}{l}\text { Pemahaman Pertanggungjawaban } \\
\text { Keuangan Dana Desa (X5) }\end{array}$ & 52 & $1-5$ & 3,01 & 1,26 & 4,26 & 2,81 & 0,84 & 0,699 \\
\hline
\end{tabular}

Sumber : Data primer yang diolah, tahun 2016

Pengujian kecocokan keseluruhan model (overall model fit) dilihat dari fungsi Likelihood L. Untuk menguji hipotesis nol dan alternatif, L ditransformasikan menjadi -2 Log L.

\section{Tabel 4}

Hasil Uji Kecocokan Keseluruhan Model (Block 0: Beginning Block)

\begin{tabular}{|c|c|c|c|}
\hline \multirow{2}{*}{\multicolumn{2}{|c|}{ Iteration }} & \multirow{2}{*}{$\begin{array}{c}-2 \text { Log } \\
\text { likelihood }\end{array}$} & \multirow{2}{*}{$\begin{array}{c}\text { Coefficients } \\
\text { Constant }\end{array}$} \\
\hline & & & \\
\hline \multirow[t]{3}{*}{ Step 0} & 1 & 70,152 & $-0,385$ \\
\hline & 2 & 70,152 & $-0,389$ \\
\hline & 3 & 70,152 & $-0,389$ \\
\hline
\end{tabular}

Sumber : Data primer yang diolah, tahun 2016
Tabel 2

StatistikDeskriptif (Variabel Y)

\begin{tabular}{|c|c|c|}
\hline Variabel Y & Frekuensi & Persentasi \\
\hline 0 & 31 & $59,6 \%$ \\
\hline 1 & 21 & $40,4 \%$ \\
\hline Total & 52 & $100 \%$ \\
\hline
\end{tabular}

Sumber : Data primer yang diolah, tahun 2016

Tabel 5
Hasil Uji KecocokanKeseluruhan Model
(Block 1: Method = Enter)


Jurnal Akuntansi dan Pajak, 20(01), 2019, 95

\begin{tabular}{||c|c|c|c|c|c|c|c|}
\hline & -2 Log & \multicolumn{6}{|c|}{ Coefficients } \\
\cline { 3 - 8 } Iteration & likelihood & Constant & rata_X1 & rata_X2 & rata_X3 & rata_X4 & rata_X5 \\
\hline 5 & 27,494 & $-24,479$ & 4,210 & 4,408 & 4,781 & $-2,939$ & $-2,966$ \\
6 & 27,494 & $-24,661$ & 4,234 & 4,442 & 4,817 & $-2,956$ & $-2,985$ \\
7 & 27,494 & $-24,663$ & 4,235 & 4,442 & 4,817 & $-2,957$ & $-2,986$ \\
8 & 27,494 & $-24,663$ & 4,235 & 4,442 & 4,817 & $-2,957$ & $-2,986$ \\
\hline
\end{tabular}

Sumber : Data primer yang diolah, tahun 2016

Jika nilai signifikansi lebih besar dari 0. 05, maka model mampu memprediksi nilai observasinya atau dapat dikatakan model dapat diterima karena cocok dengan data observasinya(Ghozali, 2013).

Tabel 6

Hasil Uji Kelayakan Model Regresi (Hosmer and Lemeshow Test)

\begin{tabular}{|c|c|c|c|}
\hline Step & Chi-square & Df & Sig. \\
\hline 1 & 1,694 & 8 & 0,989 \\
\hline
\end{tabular}

Sumber : Data primer yang diolah, tahun 2016

Tabel 6 menunjukkan nilai signifikansinya sebesar 0,989. Karena 0,989 > 0,05 maka dapat disimpulkan bahwa model regresi layak dan mampu memprediksi nilai observasinya.

Tabel 7

Hasil Uji Multikolonieritas

\begin{tabular}{||l|r|r|}
\hline \multirow{2}{*}{ Model } & \multicolumn{2}{|c|}{ Collinearity Statistics } \\
\cline { 2 - 3 } & Tolerance & \multicolumn{1}{c|}{ VIF } \\
\hline 1 (Constant) & 0,290 & 3,446 \\
X1 & 0,234 & 4,279 \\
X2 & 0,353 & 2,833 \\
X3 & 0,157 & 6,388 \\
X4 & 0,211 & 4,728 \\
X5 & & \\
\hline
\end{tabular}

Sumber : data primer yang diolah, tahun 2016

Hasil perhitungan uji multikolinieritas pada tabel 7 di atas menunjukkan bahwa variabel indepenen memiliki nilai tolerance $\geq 0.10$ yang berarti tidak terdapat korelasi antar variabel independen. Sedangkan hasil perhitungan Variance Inflation Factors (VIF) menunjukkan bahwa kedua variabel independen memiliki nilai VIF $\leq 10$. Dapat disimpulkan bahwa tidak terdapat multikolinieritas antar variabel dalam model regresi.
Tabel 8

Matriks Klasifikasi

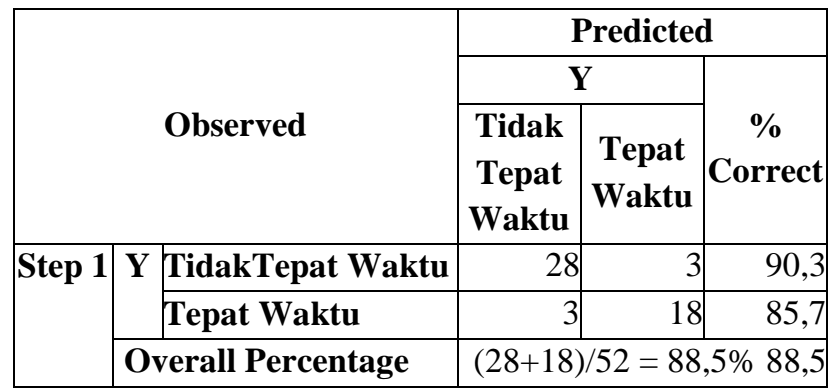

Sumber : data primer yang diolah, tahun 2016

Regresi logistic ingin menguji apakah probabilitas terjadinya variabel terikat dapat diprediksi dengan variabel bebasnya(Ghozali, 2013). Hasil pengujian model regresilogistik berganda diperoleh sebagai berikut :

Tabel 9

Hasil Uji Regresi

\begin{tabular}{|c|c|c|c|c|c|c|}
\hline & B & Wald & Df & Sig. & $\operatorname{Exp}(B)$ \\
\hline \multirow[t]{6}{*}{ Step $1^{\mathrm{a}}$} & rata_X1 & 4,235 & 5,043 & 1 & 0,025 & 69,034 \\
\hline & rata_X2 & 4,442 & 4,158 & 1 & 0,041 & 84,952 \\
\hline & rata_X3 & 4,817 & 5,393 & 1 & 0,020 & 123,605 \\
\hline & rata_X4 & $-2,957$ & 3,604 & 1 & 0,058 & 0,052 \\
\hline & rata_X5 & $-2,986$ & 2,968 & 1 & 0,085 & 0,051 \\
\hline & Constant & $-24,663$ & 8,243 & 1 & 0,004 & 0,000 \\
\hline
\end{tabular}

Sumber : data primer yang diolah, tahun 2016

Berdasarkan tabel diatas didapat persamaan regresinya yaitu :

$$
\begin{aligned}
\mathrm{Y}= & -24,663+4,235 \mathrm{X} 1+4,442 \mathrm{X} 2+4,817 \\
& \mathrm{X} 3-2,957 \mathrm{X} 4-2,986 \mathrm{X} 2+\mathrm{e}
\end{aligned}
$$

Tabel 10

Nilai Koefisien Determinasi (Nagelkerke R Square)

\begin{tabular}{|l|c|c|c|}
\hline Step & $\begin{array}{c}-2 \text { Log } \\
\text { likelihood }\end{array}$ & $\begin{array}{c}\text { Cox \& Snell } \\
\text { R Square }\end{array}$ & $\begin{array}{c}\text { Nagelkerke } \\
\text { R Square }\end{array}$ \\
\hline 1 & $27,494^{2}$ & 0,560 & 0,756 \\
\hline
\end{tabular}

Sumber : data primer yang diolah, tahun 2016 


\section{Tabel 11}

\section{Uji Signifikansi Simultan (Omnibust Test of} Model Coefficients)

\begin{tabular}{|l|l|r|r|r|}
\hline \multicolumn{2}{|c|}{} & Chi-square & Df & \multicolumn{1}{c|}{ Sig. } \\
\hline \multirow{4}{*}{ Step 1 } & Step & 42,659 & 5 &, 000 \\
\cline { 2 - 5 } & Block & 42,659 & 5 &, 000 \\
\cline { 2 - 5 } & Model & 42,659 & 5 &, 000 \\
\hline
\end{tabular}

Sumber : data primer yang diolah, tahun 2016

Berdasarkan tabel 10 diperoleh nilai koefisien determinasi sebesar 0,756 yang berarti $75,6 \%$ perubahan variabel $\mathrm{Y}$ bisa dijelaskan oleh perubahan variabel $\mathrm{X}$. Sedangkan sisanya $24,4 \%$ dijelaskan oleh variabel lain yang tidak termasuk dalam penelitian ini.

Variabel Pemahaman

Perencanaan

Keuangan Desa (X1) menunjukkan nilai koefisien regresi $(\beta 1) \neq 0$ yaitu 4,235 dengan nilai signifikansi sebesar 0,025 . Nilai ini $<0,05$, artinya variabel ini mempunyai pengaruh parsial yang signifikan terhadap $\mathrm{Y}$ dengan demikian H1 diterima. Responden yang berpendidikan SMA sebanyak $75 \%$ dan S1 sebanyak 23\%, sehingga responden cukup paham terhadap perencanaan keuangan desa, khususnya tentang APBDes. Hasil penelitin di atas menunjukkan hasil yang sejalan dengan Jaka Winarna dan Sri Murni(Winarna, Jaka. , Murni, 2006) yang menyatakan pengetahuan dewan tentang anggaran memiliki pengaruh signifikan terhadap peran DPRD dalam pengawasan keuangan daerah.

Variabel Pemahaman Pelaksanaan

Keuangan Desa (X2) menunjukkan nilai koefisien regresi $(\beta 2) \neq 0$ yaitu 4,442 dan memiliki nilai signifikansi sebesar 0,041 . Nilai ini $<0,05$, artinya variabel ini mempunyai pengaruh parsial yang signifikan terhadap $\mathrm{Y}$ dengan demikian $\mathbf{H 2}$ diterima. Sebagian besar responden $(84,6 \%)$ sudah bekerja lebih dari 1 tahun di pemerintahan desa dan berusia di atas 31 tahun, sehingga cukup paham terhadap pelaksanaan keuangan desa. Penerimaan dan pengeluaran dana desa dilakukan melalui rekening kas desa. Hasil penelitian ini sejalan dengan penelitian Ovita Charolina(Charolina, jak, 20(01), 2019, 96

Ovita. , Husaini, 2013) yang mengemukakan hasil pada penelitian di Lingkungan KPU SeProvinsi Bengkulu, bahwa implementasi pengelolaan keuangan berpengaruh positif dan significan terhadap kualitas laporan keuangan. Hal ini menunjukan bahwa semakin tinggi tingkat implementasi pengelolaan keuangan maka semakin tinggi pula tingkat kualitas laporan keuangan.

Variabel Pemahaman Penatausahaan Keuangan Desa (X3) menunjukkan nilai koefisien regresi $(\beta 3) \neq 0$ yaitu 4,817 dan memiliki nilai signifikansi sebesar 0,020. Nilai ini $<0,05$, sehingga variabel ini mempunyai pengaruh parsial yang signifikan terhadap $\mathrm{Y}$ dengan demikian $\mathbf{H 3}$ diterima. Pemahaman piñata usahaan keuangan desa termasuk dalam tingkat "cukup paham". Penata usahaan dilakukan oleh Bendahara Desa. Bendahara adalah aparat desa yang ditunjuk kepala desa untuk menerima, menyimpan, menyetorkan, menata usahakan, membayar, dan mempertanggungjawabkan keuangan desa dalam rangka pelaksanaan APB Desa. Bendahara Desa wajib melakukan pencatatan setiap penerimaan dan pengeluaran serta melakukan tutup buku setiap akhir bulan secara tertib. Bendahara Desa wajib mempertanggung jawabkan uang melalui laporan pertanggungjawaban. Hasil penelitian ini seiring dengan Ratih(Ratih, 2012)yang menemukan bahwa pemahaman terhadap piñata usahaan keuangan daerah oleh pengelola keuangan daerah berpengaruh positif terhadap kinerja SKPD.

Variabel Pemahaman Pelaporan Keuangan Desa (X4) menunjukkan nilai koefisien regresi $(\beta 4) \neq 0$ yaitu $-2,957$ dan memiliki nilai signifikansi sebesar 0,058. Nilai ini > 0,05, artinya variabel ini tidak mempunyai pengaruh parsial yang signifikan terhadap $\mathrm{Y}$ dengan demikian $\mathrm{H4}$ ditolak. Pemahaman pelaporan keuangan desa termasuk dalam tingkat "cukup paham". Walaupun KepalaDesa dan sekretaris desa "cukup paham" tentang laporan realisasi pelaksanaan APB Desa baik berupa laporan 


\section{Jurnal Akuntansi dan Pajak, 20(01), 2019, 97}

semester pertama dan laporan semester akhir tahun tetapi tidak mempengaruhi ketepatan waktu pertanggungjawaban dana desa. Hal ini terjadi karena waktu pertanggungjawaban terhambat oleh penyelesaian pembangunan yang berasal dari dana desa tersebut yang belum selesai sampai akhir tahun sehingga belum bisa dibuatkan laporannya. Hal ini tidak sesuai dengan penelitian Siti Aliyah dan Aida Nahar (Aliyah \& Nahar, 2012) mengemukakan bahwa penyajian laporan keuangan daerah berpengaruh positif signifikan terhadap transparansi dan akuntabilitas pengelolaan keuangan daerah.

Variabel Pemahaman Pertanggungjawaban Keuangan Desa (X5) menunjukkan nilai koefisien regresi $(\beta 5) \neq 0$ yaitu $-2,986$ dan memiliki signifikansi sebesar 0,085. Nilai ini > 0,05 , artinya variabel ini tidak mempunyai pengaruh parsial terhadap $\mathrm{Y}$ dengan demikian H5 ditolak. Walaupun Kepala Desa dan Sekdes "cukup paham" tentang laporan pertanggungjawaban realisasi pelaksanaan APB Desa kepada Bupati/Walikota setiap akhir tahun anggaran tetapi kalau pembangunan infrastruktur terlambat maka belum bisa melaporkan dan mempertanggungjawabkan dana desa.

Selisih -2 Log L sebelum dan sesudah variabel independen dimasukkan yaitu sebesar 42,659 (70,152 - 27,494). Model hanya dengan konstanta saj amemiliki df 51. Model dengan konstanta dan variabel bebas memiliki df. $\chi 2$ tabel sebesar 11,0705 pada df $5(51-46)$. Nilai $\chi^{2}$ hitung $>\chi 2$ tabel yaitu $42,659>11,0705$ dengan signifikansi sebesar 0,000. Karena nilaisignifikansi $<0,05$ maka dapat dikatakan Pemahaman Perencanaan (X1), Pelaksanaan (X2), Penatausahaan (X3), Pelaporan (X4), Pertanggungjawaban (X5) secara bersama-sama (simultan) merupakan mempengaruhi Ketepatan Waktu Pertanggungjawaban Dana Desa (Y). Dengan demikian, H6 diterima.

\section{Kesimpulan}

Hasil pengujian dan pembahasan pada bagian sebelumnya dapat disimpulkan bahwa secara parsial tingkat pemahaman aparat desa tentang perencanaan, pelaksanaan, piñata usahaan keuangan desa berpengaruh positif signifikan terhadap ketepatan waktu pertanggungjawaban dana desa, sedangkan pemahaman aparat desa tentang pelaporan dan pertanggungjawaban keuangan desa tidak berpengaruh terhadap ketepatan waktu pertanggungjawaban dana desa. Sedangkan secara simultan, pemahaman aparat desa tentang perencanaan, pelaksanaan, penatausahaan, pelaporan dan pertanggungjawaban keuangan desa berpengaruh secara signifikan terhadap ketepatan waktu pertanggungjawaban dana desa.

Peneliti selanjutnya disarankan untuk menambah variabel penelitian seperti pembinaan,pengawasan, dan indeks desa membangun. Pemerintah Kabupaten Subang disarankan untuk menggunakan ketepatan waktu pertanggungjawaban dana desa sebagai salah satu indicator penilaian kinerja kepala desa yang berpengaruh terhadap kelangsungan jabatan kepala desa.

\section{Ucapan Terima Kasih}

Terimakasih atas dukungan segenap civitas akademika Sekolah Tinggi Ilmu Ekonomi Sutaatmadja Subang yang telah membantu penyelesaian paper ini.

\section{Referensi}

Aliyah, S. , \& Nahar, A. (2012). Pengaruh Penyajian Laporan Keuangan Daerah dan Aksesibilitas Laporan Keuangan Daerah terhadap Transparansi dan Akuntabilitas Pengelolaan Keuangan Daerah Kabupaten Jepara. Akuntansi \& Auditing, 8/No. 2/Me, 97-189.

Charolina, Ovita. , Husaini, A. (2013). Pengaruh Implementasi Pengelolaan Keuangan dan Pengalaman Kerja terhadap Kualitas Laporan Keuangan Komisi Pemilihan Umum. Fairness, Volume 3, 82-94.

Dewi. , N. M. R. K. (2014). Pengaruh Pemahaman Sistem Akuntansi Keuangan Daerah dan Pengelolaan Keuangan Daerah terhadap Kualitas Informasi Laporan 


\section{Jurnal Akuntansi dan Pajak, 20(01), 2019, 98}

Keuangan Pemerintah Daerah (Studi Empiris Pada 10 Skpd Berupa Dinas Di Kabupaten Jembrana. Singaraja.

Efendi, R. (2018). Di Subang Dana Desa Baru Terserap 60 Persen. Retrieved from http://rri. co. id/post/berita/557470/daerah/di_subang_da na_desa_baru_terserap_60_persen. html

Ghozali, I. (2013). Aplikasi Analisis Multivariate dengan Program SPSS (Edisi Ketu). Semarang: Badan Penerbit Universitas Diponegoro.

Hair. (1998). Multivariate Data Analysis (Fifth Edit). New Jersey: Prentice Hall, Upper Saddle River.

Ipak Ayu H Nurcaya. (n. d. ). PENYALURAN DANA DESA :Medio April, Transfer ke Desa Baru Rp2,1 Triliun. Retrieved from https://ekonomi. bisnis. com/read/20180417/9/785320/laporandana-desa-per-16-april-2018-desa-baruditransfer-rp21-triliun

Lubis, A. I. (2014). Akuntansi Keperilakuan. Jakarta: Salemba Empat.

Manansal, A. A. (2013). Kecerdasan Emosi Mahasiswa Akuntansi Fakultas Ekonomi dan Bisnis Pengaruhnya Terhadap Tingkat Pemahaman Akuntansi. EMBA, 1(3), 901910.

Menteri Dalam Negeri Republik Indonesia. Permendagri No. 113 Tahun 2014. , (2014). Menteri Dalam Negeri Republik Indonesia. PERATURAN MENTERI DALAM NEGERI REPUBLIK INDONESIA NOMOR 39. , (2015).

Menteri Keuangan Republik Indonesia. (2015). Dana Desa Tahap III Siap Disalurkan, Asal. . . Retrieved from https://www. kemenkeu. go. id/publikasi/berita/dana-desa-tahap-iiisiap-disalurkan-asal/

Peraturan Presiden No. 2 tentang Rencana Pembangunan Jangka Menengah Nasional (RPJMN) Tahun 2015 - 2019. (2015).

Presiden Republik Indonesia. (2014). Peraturan Pemerintah Nomor 60 tentang Dana Desa yang bersumber dari APBN.

Presiden Republik Indonesia. Peraturan Presiden Nomor 36 Tahun 2015 Tentang Rincian APBN TA 2015. , (2015).

Presiden Republik Indonesia. UNDANGUNDANG REPUBLIK INDONESIA NOMOR 3 TAHUN 2015. , (2015).

Presiden Republik Indonesia. Peraturan
Pemerintah Nomor 8 tentang Dana Desa yang bersumber dari Anggaran Pendapatan dan Belanja Negara. , (2016).

Ratih. (2012). Pengaruh Pemahaman Sistem Akuntansi Keuangan Daerah, Penatausahaan Daerah dan Pengelolaan Barang Milik Daerah terhadap Kinerja SKPD pada Pemerintah Provinsi Kepulauan Riau. Universitas Sumatra Utara.

Santoso, S. (2012). Panduan Lengkap SPSS Versi 20. Jakarta: PT Elex Media Komputindo.

Sari, Erna. , Saiful. Aprilia, N. (2013). Pengaruh Pemahaman Sistem Akuntansi Pemerintahan dan Penatausahaan Keuangan Daerah Terhadap Kinerja Pengelolakeuangan Daerah. Jurnal Fairness Volume 3, Nomor 3. , 3, 19-29.

Sekaran, U. (2006). Research Methods For Business: Metodologi Penelitian untuk Bisnis. Salemba Empat.

Sugeng. (2014). Faktor-Faktor yang Mempengaruhi Pengelolaan Keuangan Daerah dan Implikasinya terhadap Kinerja Pemerintah Daerah di Kabupaten Kediri. Riset Ekonomi Dan Bisnis, 2.

Sujarweni, V. W. (2015). Akuntansi Desa Panduan Tata Kelola Keuangan Desa. Yogyakarta: Pustaka Baru Press.

Winarna, Jaka. , Murni, S. (2006). Pengaruh Personal Background, Political Background dan Pengetahuan Dewan Tentang Anggaran Terhadap Peran DPRD Dalam Pengawasan Keuangan Daerah (Studi Kasus Di Karesidenan Surakarta Dan Daerah Istimewa Yogyakarta Tahun 2006). Simposium Nasional Akuntansi, X Unhas Ma.

Yuliani, Safrida. , Nadirsyah,. Bakar, U. (2010). Pengaruh Pemahaman Akuntansi, Pemanfaatan Sistem Informasi Akuntansi Keuangan Daerah dan Peran Internal Audit Terhadap Kualitas Laporan Keuangan Pemerintah Daerah (Studi Pada Pemerintah Kota Banda Aceh). Telaah \& Riset Akuntansi, 3, 206-220.

Yusuf Adji. (2015). Penyerapan Dana Desa di Subang Masih Kecil. Retrieved from https://www. pikiran-rakyat. com/jawabarat/2015/11/09/penyerapan-dana-desa-disubang-masih-kecil. 